\title{
Quality of Yellow Bell Pepper Fruits Cultivated in Fertilized Soil with Yellow Water and Cassava Wastewater
}

\author{
J. G. Ramos ${ }^{1}$, M. T. C. C. do Nascimento ${ }^{1}$, R. F. B. Guimarães ${ }^{1}$, M. de O. Pereira ${ }^{1}$, V. E. Borges ${ }^{1}$, \\ N. C. de Araujo $^{1} \&$ J. S. dos Santos ${ }^{2}$ \\ ${ }^{1}$ Centro de Tecnologia e Recursos Naturais, Universidade Federal de Campina Grande, Paraíba, Brazil \\ ${ }^{2}$ Unidade Acadêmica de Tecnologia do Desenvolvimento, Universidade Federal de Campina Grande, Paraíba, \\ Brazil \\ Correspondence: J. G. Ramos, Unidade Acadêmica de Recursos Naturais, Universidade Federal de Campina \\ Grande, Paraíba, Brazil. Tel: 83-9-9660-4418. E-mail: jailtonbiossistemas@gmail.com
}

Received: July 25, 2017

Accepted: August 31, $2017 \quad$ Online Published: September 15, 2017

doi:10.5539/jas.v9n10p213

URL: https://doi.org/10.5539/jas.v9n10p213

\begin{abstract}
Currently there is a great need for reuse of water in agricultural activity, aiming at reducing environmental impacts and production costs. The objective of this study was to evaluate the fruit production of hybrid Satrapo bell pepper, under fertilization with yellow water and cassava wastewater. The experiment was conducted in a greenhouse located at Campina Grande city, PB. The experimental design was completely randomized, with eight treatments and five replications, totaling 40 experimental plots. The treatments were characterized by fertilization with cattle manure (EB); NPK; human urine (HU); cassava wastewater (M); cassava wastewater and human urine $(\mathrm{UH}+\mathrm{M})$; the double volume of human urine $(2 \mathrm{xUH})$; the double volume of cassava wastewater $(2 \mathrm{xM})$; and the double volume of human urine and cassava wastewater $(2 \mathrm{xUH}+\mathrm{M})$. At 60 day after transplanting (DAT) were evaluated the diameter, thickness of mesocarp, fresh and dry phytomass and number of lobes of yellow bell pepper fruits.According to the results, there were significant differences in the variables analyzed due to the treatments applied. The treatment corresponding to $2 \mathrm{xM}$ provided the highest results for length, diameter, thickness of the mesocarp, fresh and dry phytomass of the bell pepper fruits. On the contrary, 2xUH was the treatment that provided the lowest values for these variables and provided the highest number of lobes.
\end{abstract}

Keywords: Capsicum annuum L., biofertilizer, human urine

\section{Introduction}

The bell pepper (Capsicum annuиm L.) is among the main vegetables grown in Brazil, it is a food with high nutritional value, source of several vitamins, such as A, C and E, medicinal characteristic due to the high content of antioxidant properties (Tanwar et al., 2013).

Among the characteristics of the bell pepper fruit, considered extremely important for commercialization, the length and diameter stand out (Blat et al., 2007). These characteristics are still important in defining the shape of these fruits that it's fundamental to determine the group to which they belong whether conical, rectangular or square.

Agricultural production and agribusiness represents activities with significant negative environmental impact by the generation and production of inorganic wastes commonly used in this environment, as is the case of chemical fertilizers, which since its manufacture already negatively impact the environment by the emission of POP's (Persistent Organic Pollutants). Thus it is essential to search for alternative production systems that minimize these damages. According to Bertoncini (2014), the reuse of waste in agriculture has become a viable practice to bring varied environmental benefits by the exploration of organic material, the return of biogeochemical elements to their respective cycles, and the reduction of costs with industrialized fertilizers, which are generally imported.

The reuse of wastewater is being studied as a source of maintenance of soil fertility and reduction of the use of water of superior quality, pointing to the efficient use of these effluents with potential for agricultural production preserving good quality water which may be used for other purposes more noble, like human and animal use. 
The knowledge that wastewater treatment is vital to public health and conservation of water sources it has contributed to the development of treatment technologies, especially in developed countries (Costa et al., 2009).

According to TERA (2014), the reuse of water is based on the reutilization of water after satisfy its initial function. There is a high generation of various types of wastewater that can be reused in agriculture, such as cassava wastewater and human urine.

According to Duarte et al. (2012), the cassava wastewater is a liquid residue resultant from process for the manufacture of flour and extraction of cassava starch (Manihot esculenta) presenting high levels of sugars, starches, proteins, linamarin and salts, among other substances. According to Cardoso et al. (2009) this is a residue extremely prejudicial to the environment when disposed inappropriately, however, its use as a biofertilizer in agriculture becomes possible because it has considerable amounts of macro and micronutrients.

The yellow waters, in turn, also have promising potential as an agricultural biofertilizer due to the high concentration of nutrients as, nitrogen, phosphorus and potassium, and may complement or even replace industrialized fertilizers nitrogenous commonly used in agricultural production (Vinnerås et al., 2008).

Although the polluting characteristics, the use of wastewater in agricultural areas has been pointed as an alternative to the environment and producer. The utilization of wastewater in fertirrigation of agricultural crops can increase productivity and quality of harvested products, reducing environmental pollution and production costs, and improving the chemical, physical and biological characteristics of the soil (Matos, 2007).

Thus, the objective of this work was to evaluate hybrid yellow bell pepperfruits Satrapo (Capsicum Annuum L.) production cultivated under protected environment and submitted to fertilization with yellow water and cassava wastewater.

\section{Material and Methods}

The experiment was conducted between October and December 2016 under protected environment on Campus I of the Federal University of Campina Grande (UFCG), in the city of Campina Grande-PB $\left(7^{\circ} 13^{\prime} 50^{\prime \prime} \mathrm{S}\right.$; $35^{\circ} 52^{\prime} 52^{\prime \prime} \mathrm{W}$ and $551 \mathrm{~m}$ a.s.1.). The greenhouse had the dimensions of $32 \mathrm{~m}$ long and $20 \mathrm{~m}$ wide, with an area of $640 \mathrm{~m}^{2}$, with a metallic structure, being of the covering and arch type, covered with low density polyethylene of $150 \mu \mathrm{m}$ and sides covered with a shading screen with a protection index of $80 \%$.

To record the maximum, minimum and relative air humidity inside the greenhouse a digital thermohygrograph was used, data collected occurred every day in the morning at nine o'clock.

The Figure 1 shows the values of the maximum and minimum air temperature and air relative humidity inside the greenhouse for the first 15 days after starting the fruiting stage.

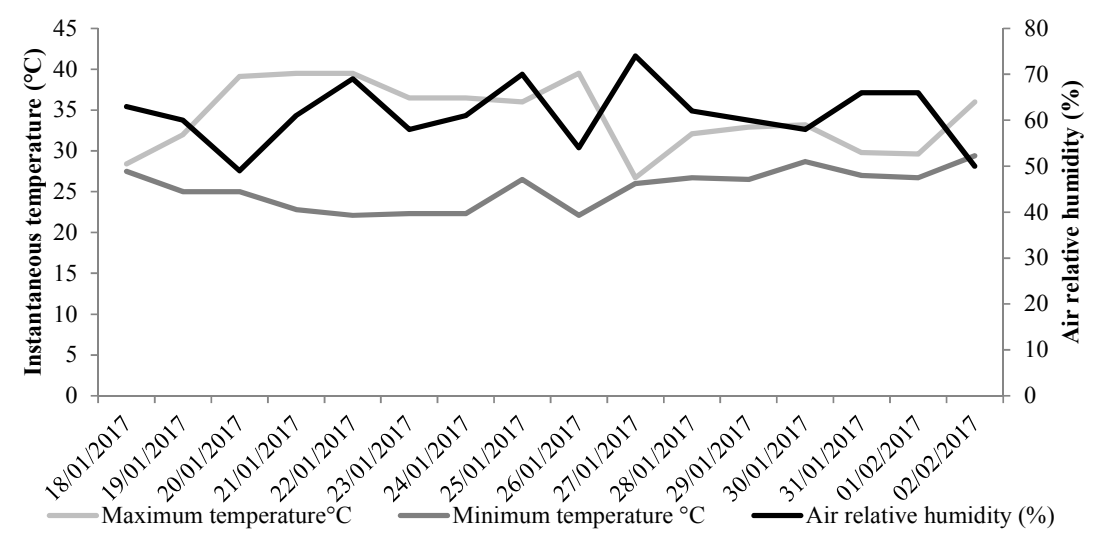

Figure 1. Air temperatures $\left({ }^{\circ} \mathrm{C}\right)$ and air relative humidity $(\%)$ inside the greenhouse

A completely randomized design was used, with eight treatments and five replications, totaling 40 experimental plots. The treatments were characterized by fertilization with cattle manure (EB) (T1); NPK (T2); human urine (HU) (T3); cassava wastewater (M) (T4); cassava wastewater and human urine (UH+M) (T5); double of the human urine volume (2xUH) (T6); double of the cassava wastewater volume (2xM) (T7) and double of human urine and cassava wastewater volume applied $(2 \mathrm{xUH}+\mathrm{M})(\mathrm{T} 8)$. 
The experimental units were composed of $20 \mathrm{~L}$ polyethylene pots placed at a height of $0.5 \mathrm{~m}$ from the ground level, distributed in rows arranged at $0.5 \mathrm{~m}$ distance and line spaced at $1 \mathrm{~m}$.

Each pot was drilled at its base for the introduction of a $0.15 \mathrm{~m}$ long and $6 \mathrm{~mm}$ drain, where a PET bottle with 2 L capacity was coupled, through which recirculation of percolated effluent was performed.

The pots were filled in their base with a layer of $0.6 \mathrm{~kg}$ of gravel number 0 and $15 \mathrm{~kg}$ of clay-loam soil coming from Esperança city, PB. The soil was fragmented and sieved in a $4 \mathrm{~mm}$ mesh screen and subsequently submitted to the physical-chemical analysis. The soil characteristics are presented in Table 1.

The cattle manure used in the fertilization came from the experimental station of the National Institute of the Semi-Arid (INSA), Table 1.

Table 1. Physical and chemical characterization of the soil and cattle manure used in the experiment

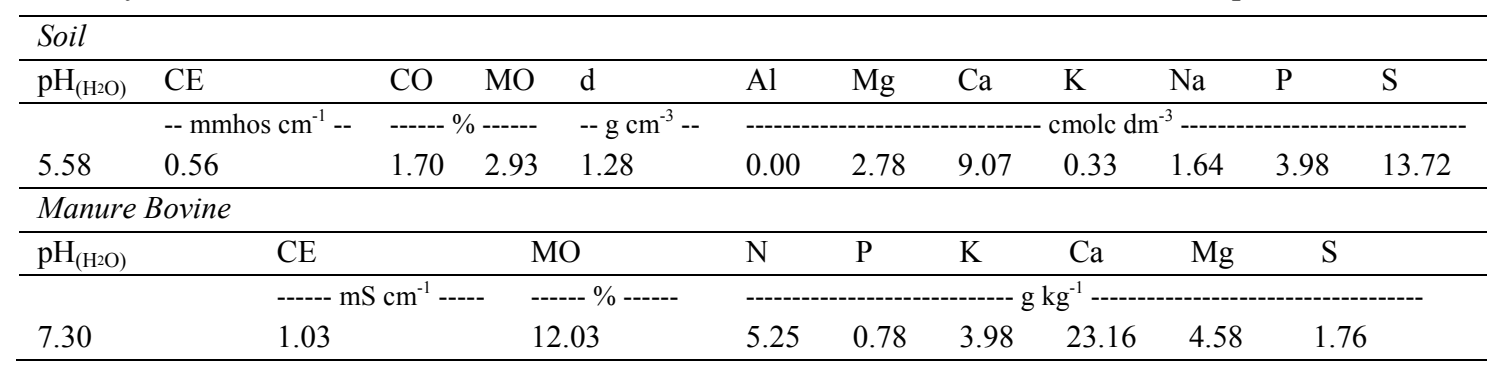

The chemical fertilization was performed using urea $(45 \%$ of $\mathrm{N})$ as a source of nitrogen, of simple superphosphate $\left(60 \% \mathrm{P}_{2} \mathrm{O}_{5}\right)$ as a source of phosphorus and potassium chloride $(60 \% \mathrm{KCl})$ as a source of potassium.

The human urine was collected in three residences and submitted to an anaerobic treatment, being stored in a plastic container with a capacity of $20 \mathrm{~L}$ kept hermetically closed for a period of 60 days, thus increasing the $\mathrm{pH}$ and, consequently, the inactivation of possible pathogens present in the effluent.

The cassava wastewater was also submitted to anaerobic digestion treatment, where it remained for a period of 60 days in a closed plastic container with a capacity of 85 liters. An empty space of $10 \mathrm{~cm}$ was left inside, and a hose was installed on the lid of the bucket with the other end dipped in a container with water at a height of 10 $\mathrm{cm}$, for the exit of the gases generated during the biodigestion of the effluent.

After the treatment, the physical-chemical analysis of the human urine and cassava wastewater was carried out, according to the methodology recommended by Standard Methods for Wastewater (APHA, AWWA, \& WEF, 2005) (Table 2).

Table 2. Physical-chemical characterization of treated cassava wastewater and treated human urine

\begin{tabular}{|c|c|c|c|c|c|c|c|}
\hline \multirow{2}{*}{ Effluents } & \multicolumn{7}{|c|}{ Parameters } \\
\hline & NPK & $\mathrm{N}-\mathrm{NH}_{3}$ & $\mathrm{P}-\mathrm{PO}_{4}{ }^{-3}$ & $\mathrm{~K}$ & $\mathrm{Na}$ & $\mathrm{pH}$ & $\mathrm{CE}$ \\
\hline & ------- & ------- & $\mathrm{g} \mathrm{L}^{-1}$ & --------- & -------- & & $--\mathrm{dS} \mathrm{cm} \mathrm{cm}^{-1}-$ \\
\hline Human urine & 8,706 & 6,737 & 0,325 & 1,097 & 2,455 & 9,32 & 42,7 \\
\hline Cassava wastewater & 1,680 & 0,933 & 0,338 & 3,948 & 0,138 & 4,73 & 11,75 \\
\hline
\end{tabular}

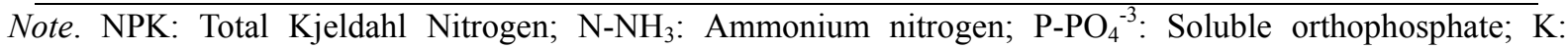
Potassium; Na: Sodium; $\mathrm{Ca}^{+} \mathrm{Mg}$ : total hardness; $\mathrm{pH}$ : hydrogenation potential and CE: Electrical Conductivity; Mani: cassava wastewater.

After the preparation of the experimental units were applied the treatments in each pot. The dose of EB was related to $40 \mathrm{tha}^{-1}$, considering a $\mathrm{N}$ mineralization rate of around $50 \%$, according to Ribeiro et al. (1999); the mineral fertilization with NPK corresponded to $5 \mathrm{~g}$ of $\mathrm{N}, 23.8 \mathrm{~g}$ of $\mathrm{P}$, and $3.8 \mathrm{~g}$ of $\mathrm{K}$, according to the recommendations of Novais et al. (1991); for the UH application was used $170 \mathrm{~mL}$ of the same, equivalent to $24.06 \mathrm{~m}^{3} \mathrm{ha}^{-1}$; the dose of M was $570 \mathrm{~mL}$ corresponding to $80.67 \mathrm{~m}^{3} \mathrm{ha}^{-1}$; for $\mathrm{UH}+\mathrm{M}$ was used $170 \mathrm{~mL}$ of human urine $+570 \mathrm{~mL}$ of cassava wastewater corresponding to $104.73 \mathrm{~m}^{3} \mathrm{ha}^{-1}$; the dose of $(2 \mathrm{xUH})$ was $340 \mathrm{~mL}$ of human urine, equivalent to $48.12 \mathrm{~m}^{3} \mathrm{ha}^{-1}$; already for the application of (2xM) the volume of $1140 \mathrm{~mL}$ of cassava 
wastewater was used, corresponding to $161,34 \mathrm{~m}^{3} \mathrm{ha}^{-1}$; and for $2 \mathrm{x}(\mathrm{UH}+\mathrm{M})$ it was applied the volume of $340 \mathrm{~mL}$ of $\mathrm{UH}+1140 \mathrm{~mL}$ of cassava wastewater, corresponding to $209.46 \mathrm{~m}^{3} \mathrm{ha}^{-1}$, was used. The volumes of human urine and cassava wastewater used were based on the concentration of total nitrogen and potassium, respectively, as recommended by Novais et al. (1991).

After the treatments were applied, the experimental units were maintained in field capacity for eight days, to stabilize the effluent in the soil.

The seedlings were produced in $150 \mathrm{~mL}$ capacity disposable cups containing earthworm humus substrate and clay-loam soil in the ratio 1:1 volume/volume. After a period of 30 days plants were selected according to height, leaf quantity and turgor to be transplanted in the pots. For irrigation of the seedlings and later the transplanted plants, rainwater was used, with electrical conductivity (EC) of $0.04 \mathrm{dS} \mathrm{m}^{-1}$. A water slide was applied daily depending on the difference in volume applied in the previous day and the volume drained in following day, according to the principle of drainage lysimetry so that the soil remained close to the field capacity (Bernardo et al., 2008). After the application of the treatments, only one Satrapo hybrid bell pepper plant was transplanted in each pot.

At 60 days after transplanting (DAT), all fruits were collected to evaluate: length of the fruit (CF), measured with a graduated scale in $\mathrm{cm}$; average diameter (DF) and mesocarp thickness (ME), determined using a digital caliper in $\mathrm{mm}$; number of lobes (NL), performed by direct counting; fresh fruit phytomass (FMF), performed by weighing the fruits in a digital scale; and dry phytomass (FMS) performed by weighing the dry fruits, in a digital escale with an accuracy of $0.001 \mathrm{~g}$.

For the evaluation of FMS, the fruits were cut longitudinally, placed in paper bags submitted to forced air circulation at $65^{\circ} \mathrm{C}$ until reaching constant weight.

The results were subjected to analysis of variance and the averages were compared by Tukey test at a $5 \%$ probability level. The statistical analyzes were performed by the software Assistat 7.7 Beta (Silva \& Azevedo, 2016).

\section{Results and Discussions}

In Figure 2 it is possible to observe that the highest lengths of the pepper was obtained for the treatments with th double of the cassava wastewater volume (2xM), cassava wastewater (M) and human urine (UH). The $2 \times M$ treatment provided the largest increase in this variable. In contrast, the treatment that promoted the shorter length of the bell pepper fruit was the double dose of human urine volume $(2 \mathrm{xUH})$. It may be related to a possible salinization of the soil as well as observed by Santos (2015). The author, in his research using human urine as an alternative source of nutrients for bermuda grass fertilization, found that during the crop establishment period the urine doses significantly modified the soil $\mathrm{pH}$ and electrical conductivity, indicating the salinization of the soil due to higher urine doses.

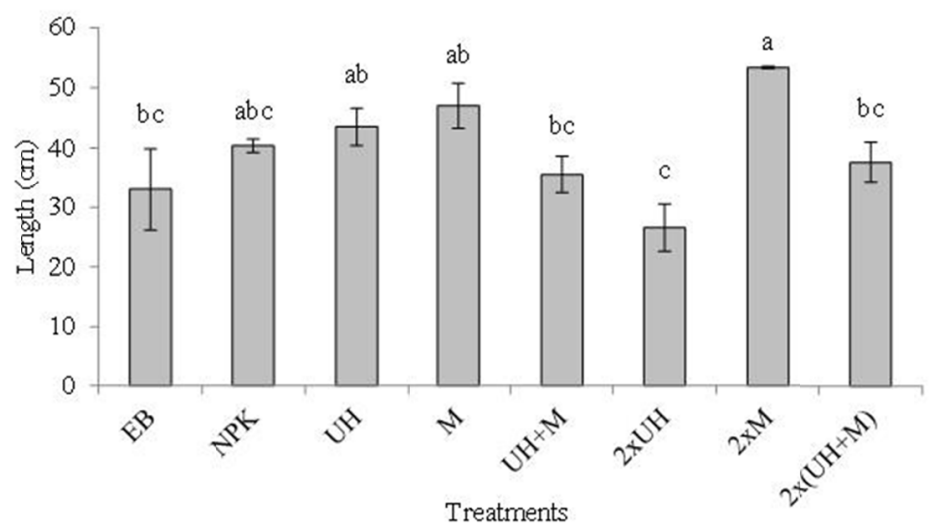

Figure 2. Length fruit (CF) of yellow bell pepper due to the treatments applied

Note. Equal letters do not differ statistically from each other by the Tukey's test $(\mathrm{p}<0.05)$. Bars represent the standard error of the average $(n=8)$. 
Similar to the length, the diameter of the bell pepper fruit increased when submitted to double of cassava wastewater volume $(2 \mathrm{xM})$ corresponding to an application of $161.34 \mathrm{~m}^{3} \mathrm{ha}^{-1}$ of cassava wastewater as biofertilizer (Figure 3).

The smaller fruit diameters were also observed in function of the treatment with 2xUH (Figure 2). According to Botto (2013) when it is intended to use human urine as fertilizer, a great concern is the presence of salts such as $\mathrm{Na}^{+}$and $\mathrm{Cl}^{-}$, because when in high concentrations they can cause damage to the soil and plants, which may justify the response of this variable.

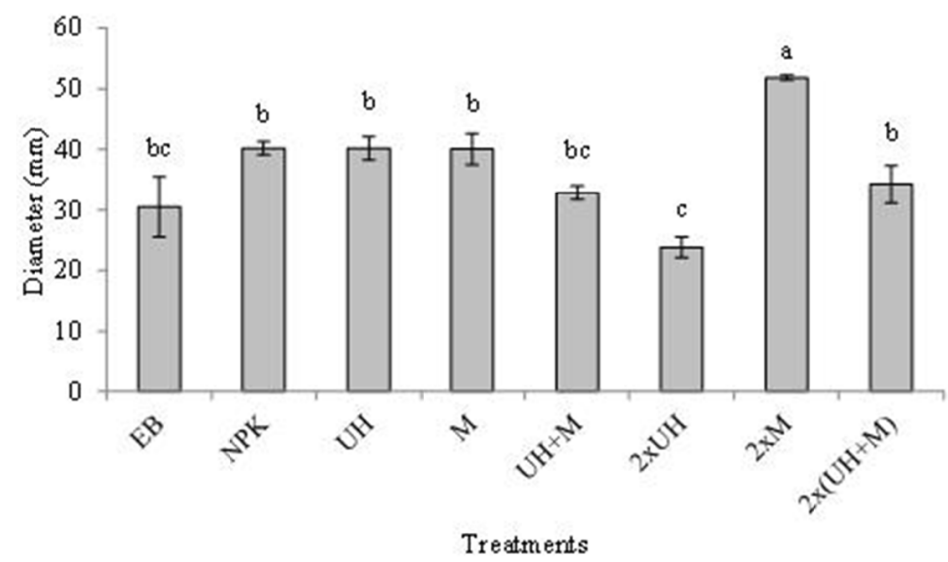

Figure 3. Fruit diameter (DF) of the yellow bell pepper due to the treatments applied

Note. Equal letters do not differ statistically from each other by the Tukey's test $(\mathrm{p}<0.05)$. Bars represent the standard error of the mean $(n=8)$.

It was observed that there was a statistically significant difference for all variables analyzed in function of applied treatments, with $1 \%$ of probability for fruit length (CF), fruit diameter (DF), fresh phytomass (FMF), dry phytomass (FMS) and mesocarp thickness (ME), and 5\% of probability level for number of lobes (NL), Table 3.

Table 3. Analysis of variance and averages of fruit length (CF), average diameter (DF), mesocarp thickness (EM), number of lobes (NL), fresh phytomass (FMF) and dry phytomass (FMS) of yellow bell pepper subjected to the treatments applied

\begin{tabular}{lllllll}
\hline FV & CF & DF & FMF & FMS & EM & NL \\
\hline QM & $359.24675^{* *}$ & $364.12935^{* *}$ & $728.35093^{* *}$ & $117.33326^{* *}$ & $4.90007^{* *}$ & $0.17159^{*}$ \\
CV\% & 18.56 & 13.57 & 28.27 & 38.56 & 18.74 & 7.85 \\
\hline EB & $33.02 \mathrm{bc}$ & $30.48 \mathrm{bc}$ & $8.29 \mathrm{~d}$ & $9.93 \mathrm{abc}$ & $3.65 \mathrm{~b}$ & $2.96 \mathrm{ab}$ \\
$\mathrm{NPK}$ & $40.38 \mathrm{abc}$ & $40.23 \mathrm{~b}$ & $22.01 \mathrm{bc}$ & $11.60 \mathrm{ab}$ & $3.87 \mathrm{~b}$ & $3.25 \mathrm{a}$ \\
$\mathrm{UH}$ & $43.54 \mathrm{ab}$ & $40.25 \mathrm{~b}$ & $30.18 \mathrm{abc}$ & $13.85 \mathrm{ab}$ & $4.10 \mathrm{~b}$ & $3.30 \mathrm{a}$ \\
$\mathrm{M}$ & $47.03 \mathrm{ab}$ & $40.11 \mathrm{~b}$ & $33.58 \mathrm{ab}$ & $17.77 \mathrm{a}$ & $3.85 \mathrm{~b}$ & $3.06 \mathrm{ab}$ \\
$\mathrm{UH}+\mathrm{M}$ & $35.54 \mathrm{bc}$ & $32.88 \mathrm{bc}$ & $23.05 \mathrm{bc}$ & $9.83 \mathrm{abc}$ & $3.76 \mathrm{~b}$ & $3.16 \mathrm{ab}$ \\
$2 \mathrm{xUH}$ & $26.54 \mathrm{c}$ & $23.80 \mathrm{c}$ & $8.17 \mathrm{~d}$ & $2.70 \mathrm{c}$ & $2.89 \mathrm{~b}$ & $3.04 \mathrm{ab}$ \\
$2 \mathrm{xM}$ & $53.63 \mathrm{a}$ & $52.42 \mathrm{a}$ & $43.28 \mathrm{a}$ & $15.63 \mathrm{a}$ & $6.33 \mathrm{a}$ & $3.0 \mathrm{ab}$ \\
$2 \times(\mathrm{UH}+\mathrm{M})$ & $37.50 \mathrm{bc}$ & $34.21 \mathrm{~b}$ & $19.87 \mathrm{~cd}$ & $6.87 \mathrm{bc}$ & $4.09 \mathrm{~b}$ & $2.71 \mathrm{~b}$
\end{tabular}

Note. ${ }^{*}, * *$ : significant at $5 \%$, and $1 \%$ probability, respectively; averages followed by the same letter in the column do not differ by Tukey's test at 5\% probability; QM: Average squares; CV: Coefficient of variation.

In general, it was observed that treatment corresponding to twice the volume of cassava wastewater applied (2xM) provided the best results in all variables, except for the number of lobes that obtained higher values when applied NPK and human urine (UH) treatments. 
Regarding the fruit length variable $(\mathrm{CF})$, average value of $53.63 \mathrm{~mm}$ was reached when $2 \mathrm{xM}$ treatment was used. This result was superior to the results obtained by Rinaldi et al. (2008) that evaluating the physical-chemical and nutritional characteristics of bell pepper cultivars, who found an average fruit length of $13.4 \mathrm{~mm}$. The results differed also from Charlo et al. (2009) and Cesar et al. (2007) that obteined the length of the bell pepper fruit between 7.96 and $12.06 \mathrm{~mm}$.

The average fruit diameter (DF) also presented the best result $(52.42 \mathrm{~mm})$ for $2 \mathrm{xM}$ treatment. This result is in agreement with Borges (2012) that obtained the diameter of the bell pepper fruit of $59.5 \mathrm{~mm}$, when the higher dose of biofertilizer was applied.

The thickness of the mesocarp (ME) presented values ranging from 2.89 to $6.33 \mathrm{~mm}$ depending on the applied treatments, highlighting the biofertilizer with application of $2 \mathrm{xM}$ per provide higher values. As well as Frizzone et al. (2001), which found a thickness of the mesocarp of the bell pepper varying from 2.6 to $5.3 \mathrm{~mm}$. Santos et al. (2017) evaluating several bell pepper genotypes, obtained values of this between 4.17 and $7.70 \mathrm{~mm}$.

The average temperature inside the greenhouse was $31.5^{\circ} \mathrm{C}$, which may have negatively affected the growth and production of the yellow pepper. According to Maldonado (2001), the appropriate temperature during the flowering and fruiting period is contained between 20 and $25^{\circ} \mathrm{C}$ and temperatures above $35{ }^{\circ} \mathrm{C}$ compromise flowering and fruiting leading to flower abortion, which directly reduces production.

\section{Conclusions}

(1) The double fertilization of the recommended dose of manipueira favors the growth and production of yellow hybrid Satrapo bell pepper.

(2) Fertilization with the double dose of human urine exerts a negative influence on the growth and production of the bell pepper, with the exception of the production variable mesocarp thickness, where there were no statistical differences between the treatments, except for double dosage of cassava wastewater.

\section{References}

APHA (American Public Health Association), AWWA (American Water Works Association), \& WEF (Water Environment Federation). (2005). Standard Methods for the examination of waterand wastewater (21st ed.). Washington DC: APHA.

Bernardo, S., Mantovani, E. C., \& Soares, A. A. (2008). Manual de Irrigação (p. 611). Viçosa, UFV.

Bertoncini, E. I. (2014). Tratamento, uso e impacto de resíduos urbanos e agroindustriais na agricultura. Pesquisa \& Tecnologia, 11(1).

Blat, S. F., Braz, L. T., \& Arruda, A. D. S. (2007). Avaliação de híbridos duplos de pimentão. Horticultura Brasileira, 25, 350-354. https://doi.org/10.1590/S0102-05362007000300006

Borges, F. R. M. (2012). Cultivo do pimentão sob água tratada por energização e doses de biofertilizante (Dissertação, Universidade Federal do Ceará, Engenharia Agrícola, Fortaleza, CE).

Botto, M. P. (2013). Utilização da urina humana como biofertilizante para produção de alimentos e energia: caracterização, uso na agricultura e recuperação de nutrientes (Tese, Universidade Federal do Ceará, Fortaleza, CE).

Cardoso, E., Cardoso, D., Cristiano, M., Silva, L., Back, A. J., Bernadim, A. M., \& Paula, M. M. S. (2009). Use of Manihot Esculenta, Crantz Processing Residue as Biofertilizer in Corn Crops. Research Journal of Agronomy, 3, 1-8. https://doi.org/10.3923/rjagr.2010.39.43

Cesar, M. N. Z., Ribeiro, R. L. B., Paula, P. D., Polidoro, J. C., Manera, T. C., \& Guerra, J. G. M. (2007). Desempenho do pimentão em cultivo orgânico, submetido ao desbaste e consórcio. Horticultura Brasileira, 25(3), 322-326. https://doi.org/10.1590/S0102-05362007000300002

Charlo, H. C. O., Castoldi, R., Fernandes, C., Vargas, P. F., \& Braz, L. T. (2009). Cultivo de híbridos de pimentão amarelo em fibra da casca de coco. Horticultura Brasileira, 27(2), 155-159. https://doi.org/10.1590S0102053620170201

Costa, F. X., Lima, V. L. A., Beltrão, N. E. D. M., Azevedo, C. A. V., Soares, F. A., \& Alva, I. D. M. (2009). Efeitos residuais da aplicação de biossólidos e da irrigação com água residuária no crescimento do milho. Revista Brasileira de Engenharia Agrícola e Ambiental, 13(6), 687-693. https://doi.org/10.1590/1807-1929/ agriambi.v21n6p404-40910 
Duarte, A. S., Silva, E. F. F., Rolim, M. M., Ferreira, R. F. A. L., Malheiros, S. M. M., \& Albuquerque, F. S. (2012). Uso de diferentes doses de cassava wastewater na cultura da alface em substituição à adubação mineral. Revista Brasileira de Engenharia Agrícola e Ambiental, 16(3), 262-267. https://doi.org/10.1590/ S1415-43662012000300005

Frizzone, J. A., Gonçalves, A. C. A., \& Rezende, R. (2001). Produtividade do pimentão amarelo, Capsicum annuum L., cultivado em ambiente protegido, em função do potencial mátrico de água no solo. Acta Scientiarum, 23(5), 111-116. https://doi.org/10.4025/actasciagron.v39i4.33003

Madonado, V. (2001). O cultivo do pimentão. Revista Cultivar: hortaliças e frutas. Pelotas, Especial. Retrieved from http://www.grupocultivar.com.br/acervo/427

Matos, A. T. (2007). Disposição de águas residuárias no solo (Caderno Didático, n. 38, p. 142). Viçosa, MG: AEAGRI.

Novais, R. F., Neves, J. C. L., \& Barros, N. F. (1991). Ensaio em ambiente controlado. In A. J. Oliveira (Ed.), Métodos de pesquisa em fertilidade do solo (pp. 189-253). Brasília: Embrapa-SEA.

Ribeiro, A. C., Guimarães, P. T. G., \& Alvarer, V. H. (1999). Recomendações para uso de corretivos e fertilizantes em Minas Gerais (p. 359). Viçosa: Comissão de Fertilidade do Solo do Estado de Minas Gerais.

Rinaldi, M. M., Sandri, D.,Ribeiro, M. O., \& Amaral, A. G. (2008). Características físico-químicas e nutricionais de pimentão produzido em campo e hidroponia. Ciência e Tecnologia de alimentos, Campinas, 28(3), 558-563. https://doi.org/10.1590/S0101-20612008000300009

Santos, O. S. N. (2015). Uso de urina humana na fertilização de grama bermuda (Tese, Universidade Federal da Bahia, Escola Politécnica, Salvador, BA).

Santos, P. R., Melo, R. A., Carvalho Filho, J. L. S., Ferreira, I. V. S., Silva, F. S., Lima Filho, F. P., \& Menezes, D. (2017). Desempenho de linhagens e híbridos de pimentão em dois sistemas de poda no cultivo hidropônico. Horticultura Brasileira, 35, 129-134. https://doi.org/10.1590/s0102-053620170120

Silva, F. de A. S., \& Azevedo, C. A. V. de. (2016). The Assistat Software Version 7.7 and its use in the analysis of experimental data. African Journal of Agricultural, 11(39), 3733-3740. https://doi.org/10.5897/AJAR2016. 11522

Tanwar, A., Aggarwal, A., Kadian, N., \& Gupta, A. (2013). Arbuscular mycorrhizal inoculation and super phosphate application influence plant growth and yield of Capsicum annuum. Journal of Soil Science and Plant Nutrition, 13(1), 55-66. https://doi.org/10.4067/S0718-95162013005000006

TERA (Tratamento de Efluentes e Reciclagem Agrícola). (2014). Reúso de água: Solução viável para o reaproveitamento do recurso nas empresas. São Paulo, Abril. Retrieved November 14, 2016, from http://www.teraambiental.com.br/blog-da-tera-ambiental/reuso-de-agua-solucao-viavel-para-o-reaproveitam entodo-recurso-nas-empresas

Vinnerås B., Nordin, A., Niwagaba, C., \& Nyberg, K. (2008). Inactivation of bacteria and viruses in human urine depending on temperature and dilution rate.Water Research, 42(15), 4067-4074. https://doi.org/10.1016/ j.watres.2008.06.014

\section{Copyrights}

Copyright for this article is retained by the author(s), with first publication rights granted to the journal.

This is an open-access article distributed under the terms and conditions of the Creative Commons Attribution license (http://creativecommons.org/licenses/by/4.0/). 